\title{
Radiological, pathological and gross correlation of an isolated renal cell carcinoma metastasis to the stomach
}

Michael Kevin O'Reilly, Gavin Sugrue, Kathleen Han-Suyin, Helen Fenlon

Radiology, Mater Misericordiae University Hospital, Dublin, Ireland

\section{Correspondence to} Dr Michael Kevin O'Reilly, michael.oreilly3@gmail.com

Accepted 12 April 2017

\section{DESCRIPTION}

A 59-year-old asymptomatic woman presented for follow-up CT thorax, abdomen and pelvis (CT-TAP). Fifteen months previously she underwent a left radical nephrectomy for a T1bN0MO, $5.5 \mathrm{~cm}$ Fuhrman grade 4 clear cell renal cell carcinoma (CCRCC) (figure 1).

The CT-TAP revealed a new $3.6 \mathrm{~cm}$ peripherally enhancing, centrally necrotic, intramural lesion in the fundus of the stomach (figure 2). It was decided to biopsy the lesion via oesophago-gastro duodenoscopy (OGD). It was not apparent on direct visualisation of the stomach mucosa, thus confirming its submucosal location. In light of its location, as well as the onset of upper gastrointestinal symptoms, lack of histological diagnosis or evidence of metastatic disease, a laparoscopic sleeve gastrectomy was performed. A tan intramural mass in the fundus of the stomach was

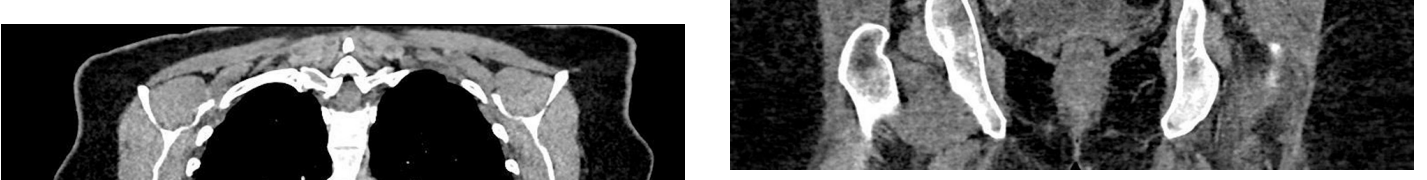

Figure 2 Portal venous phase coronal image CT-TAP 15 months later. New $3.6 \mathrm{~cm}$ centrally necrotic, intramural, peripherally enhancing lesion in the fundus of the stomach. Note absent left kidney secondary to previous nephrectomy. Small bowel mesentery lies in the left renal fossa.

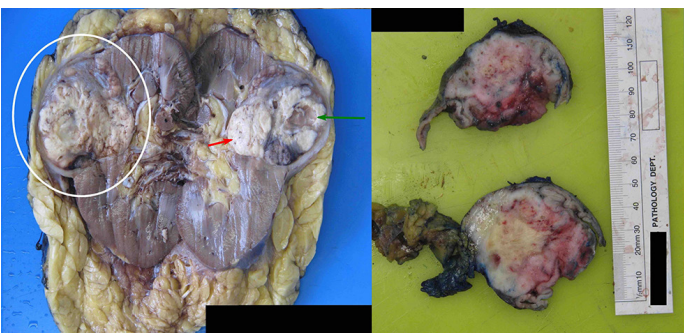

Figure 3 This is a comparison between the resected primary left kidney (left) and the intramural metachronous stomach lesion (right). The kidney has been bivalved to reveal a large, well-circumscribed tumour with a variegated tan/yellow cut surface (red arrow) and a prominent cystic area, responsible for the heterogenous appearance at CT (green arrow). Note the overall similar gross appearance to the sleeve gastrectomy specimen. Normal stomach mucosa is adjacent to the ruler. 

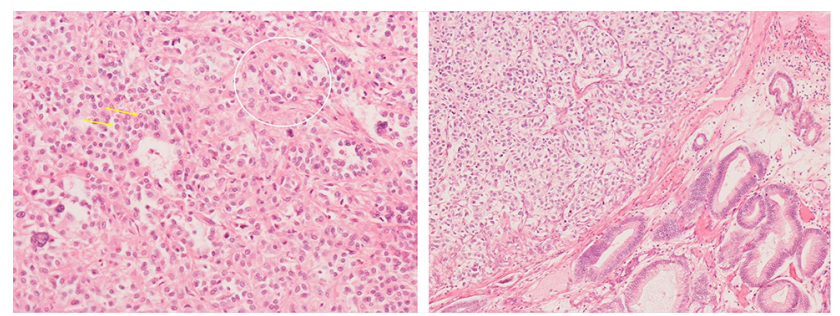

Figure 4 Low power H\&E stain of the primary CCRCC (left) and the stomach lesion (right). The tumour is composed of nested polygonal cells with predominantly small round nuclei (yellow arrows) and the classic vacuolated cytoplasm of CCRCC (example illustrated by white circle). Note the identical pattern in the resection specimen. Normal gastric mucosa is demonstrated on the right of the image. CCRCC, clear cell renal cell carcinoma.

revealed with a similar macroscopic appearance to the primary CCRCC (figure 3). H\&E staining revealed tumour cells with a nested pattern of arrangement with clear cytoplasm

\section{Learning points}

- Renal cell carcinoma (RCC) is known for unusual sites of metastatic disease with virtually any organ being involved. A solitary metastasis to the stomach is exceedingly rare.

- Case series is the best current level of prognostic evidence for gastric RCC metastasis and is associated with a poor outcome.

- Clear cell renal cell carcinoma (CCRCC) histologically is typically characterised by nested polygonal cells interspersed with intricate, arborising vasculature with predominantly small round nuclei and classic vacuolated cytoplasm. Diagnosis of metastatic CCRCC is usually achievable by routine histological examination alone. and prominent nucleoli, classic and identical to the primary CCRCC (figure 4).

The annual incidence of RCC has risen in the USA and Europe by $3 \%$ per year during the last several decades. Approximately $20 \%$ of patients will have metastatic disease at the time of diagnosis with 50\% developing metachronous metastasis post nephrectomy. ${ }^{1}$ CCRCC is known for unusual sites of metastatic spread and can typically involve the lung, bones, liver, lymph nodes or adrenal glands. A metastasis from any cause to the stomach is exceedingly rare and can account for between $0.3 \%$ and $0.8 \%$ of all gastric neoplasia. ${ }^{2}$ Such is the rarity of gastric metastasis from all histological subtypes of renal cell carcinoma, there are only approximately 25-30 cases described in the literature. The largest case series is of five patients over a 21 -year time period in 2082 patients. ${ }^{3}$ This is the best current level of prognostic evidence for gastric RCC metastases, which usually presents late in the disease process. The majority of patients show concomitant tumour spread to other organs with poor outcome. Our patient has subsequently developed peritoneal metastases and is being treated with sunitinib, an inhibitor of receptor tyrosine kinase.

Contributors MKO' $R$ was involved in the conception, data acquisition, writing and design of the manuscript. GS, KH-S and HF were involved in the conception, writing and editing of the manuscript. All authors have reviewed the final version and approved it.

Competing interests None declared.

Patient consent Obtained.

Provenance and peer review Not commissioned; externally peer reviewed.

(c) BMJ Publishing Group Ltd (unless otherwise stated in the text of the article) 2017. All rights reserved. No commercial use is permitted unless otherwise expressly granted.

\section{REFERENCES}

1 Brufau BP, Cerqueda CS, Villalba LB, et al. Metastatic renal cell carcinoma: radiologic findings and assessment of response to targeted antiangiogenic therapy by using multidetector CT. Radiographics 2013;33:1691-716.

2 Campoli PM, Ejima FH, Cardoso DM, et al. Metastatic cancer to the stomach. Gastric Cancer 2006;9:19-25.

3 Pollheimer MJ, Hinterleitner TA, Pollheimer VS, et al. Renal cell carcinoma metastatic to the stomach: single-centre experience and literature review. BJU Int 2008:102:315-9.

Copyright 2017 BMJ Publishing Group. All rights reserved. For permission to reuse any of this content visit

http://group.bmj.com/group/rights-licensing/permissions.

BMJ Case Report Fellows may re-use this article for personal use and teaching without any further permission.

Become a Fellow of BMJ Case Reports today and you can:

- Submit as many cases as you like

- Enjoy fast sympathetic peer review and rapid publication of accepted articles

- Access all the published articles

- Re-use any of the published material for personal use and teaching without further permission

For information on Institutional Fellowships contact consortiasales@bmjgroup.com

Visit casereports.bmj.com for more articles like this and to become a Fellow 